\title{
The Survey of Foreign Information Resource and Applied Study of Optimization Strategy in College
}

\author{
Dongmei Sheng ${ }^{1}$ and Jianfeng Liu ${ }^{2}$ \\ School of Foreign Languages Jilin Business and Technology College Changchun Jilin China
}

Email: 455635403@qq.com

\author{
Keywords: Information resource; Survey; Strategy ; Optimization
}

\begin{abstract}
The aim of this study is to search for the best teaching method to improve the college students' ability utilizing the information resource. This paper presents an analysis of the survey on utilization of foreign language information resources in universities. The result shows that the rate of utilizing the information resource is low. This paper analyzes the influence factors of the result and shows the strategy of reasonable utilization of foreign language information resources. The result suggests that the better teaching method in college students' ability utilizing the information resource is of great significance in improving college students' English ability.
\end{abstract}

\section{Introduction}

With the rapid development of foreign language education technology, China's colleges and universities are stepping up the construction of foreign language teaching information. Especially, the information of teaching mode has been accelerated development under the impetus of College English teaching reform. The research of foreign language educational technology includes information design of foreign language teaching and information integration of teaching resources. Foreign language teaching has the support of massive information resources, which can be used to create an authentic learning environment for students to acquire information, interact independently. However, the diversification of information resources construction does not mean the idealization of utilization effects. In the specific teaching practice, the utilization of massive resources is very limited. Therefore, how to select and optimize the teaching resources reasonably must be studied and solved. In recent years, some scholars continue to study foreign language information technology and curriculum integration, but they focuses more on the teaching process and teaching design theory. So the real concern about foreign language information resource optimization is not enough, especially the lack of convincing research. This study starts from the actual situation of College English Teaching in China, investigates the current situation of the construction of foreign language information resources and puts forward suggestions and countermeasures for the construction of the information resources on the basis of optimizing the foreign language.

\section{The Definition of Foreign Language Information Resource}

The narrow concept of foreign language information resources is all related to foreign language teaching software information, including books, electronic materials, courseware, multimedia $\mathrm{CD}-\mathrm{ROM}$ and other cyber source etc. The broad sense is the process of foreign language learning in the accumulated information, information, information technology and information creator, including the learning process, a collection of useful information for the use of foreign language teaching; improving the learning effect; language information producers; collection processing and transmission of language information in information technology. This article holds the broad understanding that the ability of information resources can be divided into the ability of information resources preparation, the ability to select information resources and the ability to develop information resources. The ability to prepare information resources means that learners have the information consciousness and information technology to create and utilize diversified foreign language information resources. The ability to select information resources refers to the ability of 
learners to have a certain basic knowledge of foreign languages, to judge the sources of information, and to collect, process and use information resources.

\section{The Definition of Integration and Optimization}

A lot of foreign language information resources integration is two or more than two parts in compliance with objective law or certain conditions and requirements, cohesion and integration as a whole process; the essential meaning of the optimization is toward a higher goal of sublimation and promotion, is a marking with development process high sense of movement and the sense of depth (Zhang Jian, 2010). Integration and optimization are two aspects of the same process of development, and the two interact and interact with each other. Integration is the means and the basis and premise of optimization. Optimization is the goal, the integration of development and sublimation. The integration is oriented to the tradition, the object is the existing things, and the optimization is to break through the tradition, and the purpose is to achieve

The greatest benefits and possibilities of innovation lead to new and better integration. The integration and optimization are for the purpose of innovation, integration innovation is the carrier of optimization is the realization of innovation, two different ways to the same. The integration and optimization of foreign language autonomous learning based on information resources, is to search, collection, screening, sorting, adaptation, transformation, integration, optimization and create a variety of forms, media language materials, the use of advanced information technology, school teachers and students together to establish foreign language information resources learning support system, provide basic information resource for creating efficient, virtual and open autonomous learning environment for students to develop knowledge, provide guarantee for the construction of information resources.

\section{The Survey of Utilization of Foreign Language Information Resources}

Investigation Process. The author conducted a questionnaire survey on the utilization of foreign language information resources in three universities in Jilin province. The survey was conducted at 303 undergraduate and 2016 non English Majors in three universities and colleges Among them, 105 were from Jilin Agricultural University, 96 from Jilin Business and Technology College, and 99 from Changchun University of Science and Technology. These three schools have different characteristics. The survey covers the types of resources available to students, the principal creators of foreign language information resources and the utilization of foreign language information resources by students. The survey methods included interviews and questionnaires. The author designs a five level Liker scale according to the types of foreign language information resources that can be used by students to investigate the utilization of foreign language information resources

The Results of the Survey. Through on-the-spot investigation and interviews, the author learned that the students of non-English majors can be used in the process of autonomous learning in information resource type: books, newspapers, magazines, CDs, courseware, network classroom and Internet resources. Creating information resources mainly depends on the school. The students get their own allotment of the school because the students' independent consciousness is weak and they lack the guidance of teachers. So the utilization rate is very low and the school gave up this aspect of the allocation of resources. The main problems in the construction of foreign language information resources in the autonomous learning process are lack of understanding of the importance of teaching management information. In the input of teaching resources, lack of overall planning, often built a multimedia classroom for autonomous learning, but it ignored the construction of information resources.

\section{The Strategy of Optimization}

Optimization should be built on sharing mechanism. The sharing of information resources is not 
only an idea, but also a process. As a concept, it always encourages learners to strive for the goal of "any person, at any time, at any place," which can obtain any information that may be acquired for foreign language learning. As a process, it is required in the process of creating foreign language information resources, strengthening cooperation and coordination between schools, teachers and students. It carries out various forms of foreign language information resources on construction and sharing of knowledge and activities. The establishment of foreign language information resources guarantees the system of different levels and gradually realizes the goal of information sharing. Information technology and infrastructure guarantees Mechanism. Without the support of modern information technology and the protection of infrastructure, it will not work to build and share foreign language information resources. Therefore, we should strengthen the information technology and infrastructure security mechanism, strengthen the local foreign language information resource construction, such as the establishment of interactive function of the professional and creating autonomous learning resources center or network language. We should combine traditional teaching resources and cyber source, integration and order on foreign language information resources, to provide the corresponding resource permissions for different roles.

\section{Conclusion}

Optimization of college foreign language information resources will promote and improve the teaching mode and teaching idea renewal, also make the information resources of College English have the characteristic and connotation of new information resources will be gradually conversion from a single variety, closed to open, static to dynamic, individual to the whole, one-way into interactive and passive reception into active search etc.. College English teaching is endowed with new features: Students' learning autonomy is strengthened, the content of learning is more diverse, the simulation learning environment is more open and real, and the guidance of teachers has been strengthened. This study will provide some suggestions on how to solve the reasonable choice and optimized utilization of information resources in higher education.

\section{Acknowledgements}

This paper is one of research findings from the project "The Survey of Foreign Information Resource and Applied Study of Optimization strategy in College which is "the 13th Five-Year" social science project in the Department of Education in Jilin Province. The project number is JJKH 20170207SK

\section{References}

[1] Gardner, D. and Miller, L. Establishing Self -Ac-cess-from Theory to Practice [M].Shanghai: Shanghai Foreign Language Education Press,2002:52.

[2] Leather, J. \& Dam, J. V. (2003). Ecology of Language Acquisition. Dordrecht: Kluwer

[3] Tudor, I. (2001). The Dynamics of the Language Classroom. Cambridge: Cambridge University Press. Academic Publishers

[4] Van Lier, L. (2004). The Ecology and Semiotics of Language Learning: A Sociocultural Perspective. Boston: Kluwer Academic.

[5] Boylan, M. (2010). Ecologies of Participation in School Classrooms. Teaching and Teacher Education, 26, 61-70.

[6] Nelson, J., Angela, C.,Learning[J]. TechTrends, Clif, M. TPACK and Web 2.0: Transformation if Teaching and 2009(5): 80-87.

[7] Dunlap, J. C., Lowenthal, P. R. Learning, unlearning, and relearning. Using Web 2.0 technologies to support the development of lifelong learning skills[J]. E-Infrastructures and Technologies for Lifelong Learning: Next Generation Environments, 2011(3): 46-52.

[8] Downs, S. Connectivism and Connective Knowledge-Essays on meaning and learning networks[EBlOL]. Retrieved November 2015 at http://www.downes.ca/me/mybooks.htm.2012.

[9] Downs, S. An Introduction to Connective Knowledge[EB1OL]. Retrieved November 2015 at 
http://www.downes.ca/post/33034. 2005.

[10] Sasha, A. R. Online learning environments in higher education: Connectivism vs. dissociation [J]. Education and Information Technology, 2015 (20): 579-588. 